\section{Knelpunten bij verslaglegging door verpleegkundigen en verzorgenden}

Verpleegkundigen en verzorgenden vinden dat zij in hun verslaglegging worden belemmerd door de voorgestructureerde digitale systemen waar zij mee werken. Ook voelen zij zich weinig ondersteund door zorgorganisaties om voldoende aandacht te kunnen besteden aan goede verslaglegging. Dit blijkt uit een analyse van de knelpunten die verpleegkundigen en verzorgenden ervaren bij hun verslaglegging.

Kim de Groot, Wolter Paans, Anke de Veer \& Anneke Francke

Verpleegkundigen en verzorgenden leggen veel gegevens over de zorgverlening bij cliënten vast. Voor de continuïteit en kwaliteit van de zorg is het belangrijk dat deze verslaglegging adequaat en volledig is. Uit verschillende onderzoeken blijkt echter dit lang niet altijd zo is (De Blok e.a., 2012; IGZ, 2015). Om de verslaglegging te verbeteren wordt momenteel de richtlijn Verpleegkundige en Verzorgende Verslaglegging (V\&VN, 2011) geactualiseerd. De herziene richtlijn zal in 2018 verschijnen en is bedoeld voor verpleegkundigen en verzorgenden werkzaam in alle zorgsectoren. Om rekening te houden met de knelpunten die zij momenteel ervaren en om tot een bruikbare richtlijn te komen, verrichtten NIVEL en Hanzehogeschool Groningen een knelpuntenanalyse.

\section{Knelpuntenanalyse}

Welke knelpunten ervaren verpleegkundigen en verzorgenden in de verslaglegging over hun zorgverlening aan cliënten? Om een antwoord op die vraag te vinden, startte de knelpuntenanalyse met een verkenning van bestaande Neder- landse onderzoeks- of beleidspublicaties over verslaglegging. Vervolgens is aan praktiserende verpleegkundigen en verzorgenden gevraagd welke knelpunten zij momenteel ervaren in hun verslaglegging en welke oplossingsrichtingen zij daarvoor zien. Hiervoor ontvingen de deelnemers van het landelijke NIVEL Panel Verpleging \& Verzorging (www.nivel.nl/ panelvenv) een online vragenlijst. De vragenlijst werd ingevuld door 908 deelnemers (De Groot e.a., 2017a). Ter verdie-
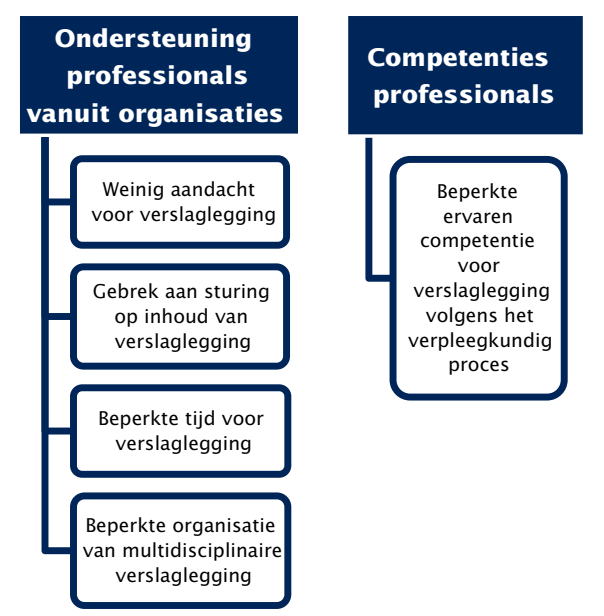

vragenlijstonderzoek, vond ook een kwalitatief groepsinterview plaats met acht verpleegkundigen en verzorgenden. Daarnaast was er een groepsinterview met vier cliënten en vier mantelzorgers en zijn er verschillende man zorgorgan zorgorganisaties geïnterviewd. Uit al deze methoden volgden vier categorieën van knelpunten (zie figuur 1).

Weinig ondersteuning vanuit organisaties

Uit de literatuurverkenning bleek het eerste knelpunt: de aandacht vanuit zorgorvan de verslaglegging van verpleegkundigen en verzorgenden schiet gemiddeld genomen tekort (o.a. de Blok e.a., 2012). Ook in het vragenlijstonderzoek gaven verpleegkundigen en verzorgenden aan dat zij weinig steun ervaren vanuit het (afdelings)management bij hun verslaglegging. het man melijk op regels en checklists en minder

Figuur I. Ervaren knelpunten van verpleegkundigen en verzorgenden bij verslaglegging. ping en aanvulling van het ganisaties voor de inhoudelijke kwaliteit op de inhoudelijke kwaliteit van de verslaglegging. 'Afvinken en checklists zijn belangrijker dan goed hulpverlenerschap' aldus een verpleegkundig specialist ggz, in de online vragenlijst.

Verpleegkundigen en verzorgenden gaven aan dat doo inhoud ook verschillende manieren van verslaglegging ontstaan. Daarnaast missen zij ook ondersteuning om met veranderingen als de digitalisering van zorgdossiers om te gaan. Zo merkten ze op dat er (te) weinig of geen scholing vanuit hun organisatie wordt aangeboden over verslaglegging. Een ander knelpunt is dat ze te weinig steun ervaren om voldoende tijd te kunnen besteden aan goede verslaglegging en overdracht. 'Verslaglegging en overdracht hoort bij kwalitatief goede zorg, maar er kan geen tijd voor geïndiceerd worden', zegt een thuiszorsverpleegkundige.

Naast hun directe collega's hebben verpleegkundigen en verzorgenden bij hun verslaglegging ook te maken met andere disciplines, zoals artsen en fysiotherapeuten. Uit de literatuurverkenning en het vragenlijstonderzoek bleek als knelpunt dat verslaglegging in samenwerking met andere disciplines weinig georganiseerd verloopt (Krijgsman e.a., 2015). In het vragenlijstonderzoek werd als reden hiervoor genoemd dat andere disciplines niet altijd toegang hebben tot de zorgdossiers waarmee verpleegkundigen en verzorgenden werken.

Beperkte ervaren competentie

Niet alleen voldoende ondersteuning, maar ook voldoende deskundigheid is van belang voor de kwaliteit van de verslaglegging. Uit de literatuurverkenning kwam echter naar voren dat er vaak nog onvoldoende deskundigheid is, zowel bij de verpleegkundigen en verzorgenden als bij het management. Zo is er bijvoorbeeld beperkte kennis over de uitgangspunten en criteria zoals die in de huidige richtlijn over verslaglegging beschreven staan (Duijvendijk e.a., 2014). In de online vragenlijst gaf tussen de 15 en 54 procent van de verpleegkundigen en verzorgenden (afhankelijk van opleidingsniveau) aan zich slechts in beperkte mate competent te voelen voor verslaglegging in aa sluiting bij het verpleegkundig proces.

Verzorgenden voelden zich hiervoor het minst vaak competent (De Groot e.a. 2017b)

Beperkte gebruiksvriendelijkheid systemen

De meeste knelpunten die verpleegkund gen en verzorgenden noemden, hebben te maken met de digitale formats en systemen die zij gebruiken voor de verslaglegging. Vooral verpleegkundigen en verzorgenden uit de ggz of die werkzaam zijn in de zorg voor mensen met een beperking gaven vaak aan dat de digitale zorgdossiers waar zij mee werken niet gebruiksvriendelijk zijn. Binnen andere zorgsectoren werd vooral genoemd dat relevante informatie in veel verschillende onderdelen van het dossier staat, wat zorgt voor een onoverzichtelijke verslaglegging. Tegelijkertijd gaven verpleegkundigen en verzorgenden ook aan dat ze soms niet alle relevante informatie kwijt konden binnen de voorgestructureerde formats van de digitale zorgdossiers. Een verzorgende uit de thuiszorg: 'Het geeft alleen een klinisch beeld, niet hoe de $c$ elkaar steekt. De kleine, fijne weetjes kan ik niet kwijt:

Ook noemden verpleegkundigen en verzorgenden vaak de gebrekkige aansluiting van verschillende digitale systemen binnen de eigen zorgorganisatie. Zo wor- den er regelmatig verschillende digitale sstemen gebruikt die niet goed met elkaar communiceren, waardoor ze op meerdere plaatsen dezelfde informatie moeten vastleggen. Daarnaast merkten ze ook op dat digitale systemen van verschillende organisaties vaak niet op elkaar aansluiten, wat zorgt voor dubbele verslaglegging en extra registratielast.

Gebrekkige betrokkenheid cliënten

Uit de literatuurverkenning (CSO e.a. 2013) en de groepsinterviews met cliënten en mantelzorgers bleek dat zij nog weinig bij de verslaglegging betrokken worden. Het verslagleggen gebeurt vaak buiten het zicht van cliënten en mantelzorgers, terwijl zij wel graag betrokken zijn bij dat wat er geschreven wordt.

Verpleegkundigen en verzorgenden noemden in de online vragenlijst ook het knelpunt dat het moeilijk is om cliënten en mantelzorgers te betrekken. Als voorbeeld noemden zij dat directe inzage in het digitale zorgdossier niet altijd gerealiseerd is, omdat cliënten en mantelzorgers niet in het digitale systeem kunnen inloggen. Cliënten en mantelzorgers herkennen dit knelpunt in het groepsinterview. 'Er wordt weinig geïnvesteerd in de informatievoorziening aan de omgeving van de patiënten', aldus een mantelzorger in het groepsinterview.

Als directe inzage wel mogelijk is, signaleren verpleegkundigen en verzorgenden dat dit voor verwarring kan zorgen bij cliënten en mantelzorgers, bijvoorbeeld wanneer rapportages niet duidelijk voor hen zijn door het gebruik van vaktaal. Ook komen verpleegkundigen en verzorgenden voor moeilijke keuzes te staan, bijvoorbeeld wanneer de informatie die ze willen rapporteren mogelijk confronterend voor de cliënt is. Een thuiszorg-ver- 
zorgende geeft als voorbeeld: 'Als er bij de cliënt ziekte-inzicht ontbreekt en als je de cliënt niet ongerust wilt maken, maar wel een overdracht voor je collega's wilt

geven.'

\section{Verwachtingen over een richtlijn}

We vroegen verpleegkundigen en verzorgenden in de vragenlijst ook of een landelijke richtlijn hen ondersteuning kan bieden tijdens hun verslaglegging. Een ruime meerderheid (84,6 procent) van de deelnemers vond van wel. Meest genoemd werd dat een richtlijn kan zorgen voor duidelijkheid over wat goede verslaglegging inhoudt en kan bijdragen aan overeenstemming tussen zorgverleners over de wijze van verslagleggen. Ook een verbetering van de overdracht van zorg tussen organisaties werd in dit verband genoemd.

\section{Tot slot}

Om aan te sluiten bij deze verwachtingen zal in de herziene richtlijn meer aandacht besteed worden aan inhoudelijke criteria waaraan de elektronische (digitale) verslaglegging moet voldoen. Hiervoor zal de richtlijn in de eerste plaats aanbevelingen voor verpleegkundigen en verzorgenden zelf bevatten. Echter, een aantal van de eerdergenoemde knelpunten zijn randvoorwaarden die buiten de directe beïnvloeding van verpleegkundigen en verzorgenden zelf liggen. Zo vragen de afstemming tussen verschillende digitale systemen en de ondersteuning vanuit zorgorganisaties ook om acties vanuit die zorgorganisaties. De herziene richtlijn biedt geen directe oplossing voor deze knelpunten. Wel komen er aanbevelingen voor het beleid en het management van zorgorganisaties in de richtlijn. Deze aanbevelingen kunnen verpleegkundigen en verzorgenden ondersteunen om invloed uit te oefenen binnen hun zorgorganisaties.

\section{Noot}

Het project rondom het actualiseren van de richtlijn is gefinancierd door ZonMw-programma Kwaliteit van Zorg: Ontwikkeling

Kwaliteitsstandaarden.

\section{Referenties}

Blok, C. de, Vat, L., Soest-Poortvliet, M. van, e.a.

(2012). Onderzoek naar de overdracht van patiëntinformatie tussen ziekenhuizen en VVT. Utrecht: NIVEL.

Centrale Samenwerkende Ouderenorganisaties (CSO), Zorgbelang Nederland, Pharos (2013). Ouderen over ondersteuning en zorg. Utrecht: CSO.

Duijvendijk, I. van \& Rest, B. van (2014). Verpleegkundige overdracht, een geoliede machine? Den Haag: Nictiz.

Groot, K. de, Veer, A.J.E. de, Paans, W. \& Francke,

A.L. (2017a). Hbo-verpleegkundigen het meest positief over hun competenties bij verslaglegging: tabellen. Utrecht: NIVEL.

Groot, K. de, Veer, A.J.E. de, Paans, W. \& Francke, A.L. (2017b). Verpleegkundige verslaglegging: hbo'ers meest positief. TVZ, Tijdschrift voor Verpleegkundigen, 2017, nr.3, pag 40-41.

Inspectie van de Gezondheidszorg (IGZ),

Ministerie van Volksgezondheid, Welzijn en
Sport (2015). Continuïteit van zorg voor kwetsbare ouderen vanuit het ziekenhuis naar verpleeg- en verzorgingshuizen, thuiszorg en huisartsen niet gewaarborgd. Utrecht: IGZ.

Krijgsman, J., Peeters, J., Burghouts, A., e.a. (2015). Tussen vonk en vlam: eHealthmonitor 2015. Den Haag/Utrecht: Nictiz/ NIVEL.

Verpleegkundigen \& Verzorgenden Nederland $(\mathrm{V} \& \mathrm{VN})(2011)$. Richtlijn Verpleegkundige en verzorgende verslaglegging. Utrecht: $\mathrm{V} \& \mathrm{VN}$.

\section{Over de auteurs}

Kim de Groot, onderzoeker NIVEL en wijkverpleegkundige Thebe Wijkverpleging. Wolter Paans, lector Verpleegkundige Diagnostiek, Hanzehogeschool Groningen. Anke de Veer, senior onderzoeker NIVEL. Anneke Francke, programmaleider NIVEL en bijzonder hoogleraar Verpleging en verzorging in de laatste levensfase, Amsterdam Public Health onderzoeksinstituut, VU medisch centrum.

\section{SAMENVATTING}

- Verpleegkundigen en verzorgenden ervaren vaak knelpunten in gebruiksvriendelijkheid en onderlinge aansluiting van digitale formats of systemen die zij gebruiken voor hun verslaglegging.

- Zij voelen zich bij hun verslaglegging ook te weinig ondersteund door het beleid en/ of management van hun organisaties.

- Cliënten en mantelzorgers worden nog weinig betrokken bij verslaglegging.

- Verwacht wordt dat een geactualiseerde, landelijke richtlijn kan bijdragen aan een vermindering van de ervaren knelpunten. 